\title{
Adaptability Evaluation and Selection of Improved Tef Varieties in Growing Areas of Southern Ethiopia
}

\section{Yasin Goa Chondie ${ }^{1 *}$ and Agedew Bekele ${ }^{2}$}

${ }^{1}$ Areka Agricultural Research Center, Areka, Ethiopia

${ }^{2}$ Awassa Agricultural Research Center, Awassa, Ethiopia

\begin{abstract}
Eight Tef varieties including local checks were evaluated with the objective of selecting adaptable, best performing varieties and to assess farmers' criteria for Tef variety selection during 2008 and 2009 cropping season at Areka and Hossana stations of Areka Agricultural Research center in the Southern region of Ethiopia. In the study the Tef varieties namely Koye, Gimbichu, Quncho, Dega Tef, Keytena, Amarach and Ajora-1 were collected from the Federal and regional Research center along with local checks, Ethiopia, and Regional Agricultural Research Institute. These materials were put into trial at Areka Agricultural Research center station farms at Areka and Hossana of Wolayta and Hadiya Zones. The trial was laid out in a randomized complete block design with three replications. Each plot measured $3 \mathrm{~m} \times 3 \mathrm{~m}$ with $1 \mathrm{~m}$ between plots and $1.5 \mathrm{~m}$ between blocks. Sowing was done within the last week of July to 1 st week of August 2008 and 2009. Data on various characters, such as plant height, panicle length, days to heading, and days to maturity and grain yield. Data was subjected to analysis of variance and there was highly significant difference $(p<0.01)$ among the varieties for grain yield and some of agronomic traits. The results for the trials indicated that there were significant yield differences between the local check and the released varieties at two stations. At Areka, the combined analysis of variance over years indicated that varieties Koye, Amarch and Quncho gave the highest grain yield viz., 988.7, 984.3 and $958.7 \mathrm{~kg} / \mathrm{ha}$ respectively. Similarly, at Hosanna, varieties Gimbichu, Quncho and koye out yielded other varieties and had yield advantage of 31.9, 25.14 and $15.14 \%$ over local variety, respectively. Both combined across locations over year's analysis and farmers' assessments identified two varieties Quncho and Koye as potential varieties for wider production. This result also indicated that farmers were as capable as Researchers in varietal choice. Therefore, based on objectively measured traits (grain yield, days to maturity, plant height, panicle length, days to heading and farmers' preference, Koye and Quncho are recommended for wider cultivation in Areka and Hossana areas of south Ethiopia while varieties (Amarach and Gimbichu) showed specific adaptability for Areka and Hossana areas respectively.
\end{abstract}

Keywords: Tef; Agricultural research; Grain yield; Maturing variety

\section{Introduction}

Tef (Eragrostis Tef (Zucc.) Trotter) is an annual grass crop and important cereal harvested for grain in Ethiopia. Ethiopia is not only the origin of Tef but it is also the center of diversity [1]. Tef is adaptable to a wide range of ecological conditions in altitudes ranging from near sea level to $3000 \mathrm{msl}$ and even it can be grown in an environment unfavourable for most cereal, while the best performance occurs between 1100 and 2950 masl in Ethiopia [2]. In the country, cereals, pulses, oil crops, vegetables and root crops are grown annually on the average, 10 million hectares. Of these 7.6 million is allocated for cereals. Tef, the single dominant, occupies 2,404,674 hectares and the production is about $24,377,495$ quintals annually [3]. Tef flour is preferred in the production of enjera, a major food staple in Ethiopia. Tef is also grown on a limited basis for livestock forage in other parts of Africa, India, Australia, and South America. In the U.S., small acreages of Tef are grown for grain production and sold to Ethiopian restaurants (Carlson, Idaho) or utilized as a late planted livestock forage (Larson, Minnesota). According to Wondimu et al. [4], Tef is primarily grown to prepare enjera, porridge and some native alcohols drinks. The straw is used for animal feed. In the 2001/2002 cropping season about $133,882.2$ ha was covered by Tef. The nutritional value of Tef grain is similar to the traditional cereals. Tef is considered to have an excellent amino acid composition, lysine levels higher than wheat or barley, and slightly less than rice or oats. Tef contains very little gluten. Tef is also higher in several minerals, particularly iron.

In Southern Nations, Nationalities, and Peoples Regional State (SNNPR), the main Tef producing zones in SNNPR are North Omo,
Gurage, Hadiya, Kembata-Tembaro Alaba and kefico Shekicho [3]. It is greatly valued by farmers and consumers. This crop is important crop for human consumption, source of cash and straw for animal feed and plastering compounds for construction purposes. Tef the most preferred crop because its straw quality for livestock feed, best 'enjera' quality, long seed storability, and drought resistance. The importance of Tef is based primarily on consumer preference for enjera (Ethiopian bread). Its agronomic versatility and reliability even under adverse conditions which suit it well to a country of contrasting and unpredictable environments where water logging, drought, pest and disease are all too common and bring repeated famine also makes this crop very important. The regional average yield of Tef is about $7.39 \mathrm{q} /$ ha in 2001/2002 [3] cropping season.

The yields of Tef are low in Ethiopia as well as in southern region due to different production problems including: lack of improved varieties, non-adoption of improved technologies, disease and pests are some of the most serious production constraints in Tef production in Ethiopia.

*Corresponding author: Yasin Goa Chondie, Areka Agricultural Research Center PO Box 79, Areka, Ethiopia, Tel: +251912135281; E-mail: yasingoac76@yahoo.com

Received December 19, 2016; Accepted January 24, 2017; Published January 31,2017

Citation: Chondie YG, Bekele A (2017) Adaptability Evaluation and Selection of Improved Tef Varieties in Growing Areas of Southern Ethiopia. Hydrol Current Res 8: 266. doi: 10.4172/2157-7587.1000266

Copyright: (c) 2017 Chondie YG, et al. This is an open-access article distributed under the terms of the Creative Commons Attribution License, which permits unrestricted use, distribution, and reproduction in any medium, provided the original author and source are credited. 
Some varieties of Tef were released by the different regional and federal research centers in Ethiopia; however, most of them were not evaluated around areas of southern Ethiopia and farmers were not participated in varietal improvement and testing process. Participation of farmers' in varietal choice has considerable value in technology evaluation and dissemination. Participatory varietal evaluation and selection is being conducted in some crops like common bean [5] and barley [6]. According to Courtois et al. [7] evaluated the effect of participation of farmers by comparing only the rankings of varieties by farmers and researchers at the same locations and reported a strong concordance between farmers and breeders in environments that have been producing contrasting plant phenotypic performance in rice. Two way feedbacks between farmers and researchers is indeed vital component of highly client-oriented breeding programs in locally important and traditionally cultivated crop [8]. Daniel et al. [9] stated that farmers' selection criteria vary with environmental conditions, traits of interest, ease of cultural practice, processing, use and marketability of the product, ceremonial and religious values. Therefore, the objectives of this study were to evaluate and select improved Tef varieties which are adaptable, high yielding and to assess farmers' criteria for variety selection with the participation of farmers in southern Ethiopia.

\section{Materials and Methods}

\section{Study area}

The experiment was conducted at Areka Agricultural Research Farm of the Hosanna and Areka stations between end of July and August, 2008 and 2009. Hosanna is located at an altitude of 2290 masl, latitude $07^{\circ} 5^{\prime} \mathrm{N}$, longitude $37^{\circ} 5^{\prime} \mathrm{E}$, temperature: $17.02^{\circ} \mathrm{C}$, rainfall: 1500-1800 mm, soil type: Profondic Luvisols (Areka Meteorological Station, 2008). Similarly, Areka is located at an altitude of 1830 masl, latitude $07^{\circ} 4^{\prime} 24^{\prime \prime} \mathrm{N}$, longitude $37^{\circ} 41^{\prime} 30^{\prime \prime} \mathrm{E}$, temperature: $20.3^{\circ} \mathrm{C}$, rainfall: $1200-1700 \mathrm{~mm}$, soil type: Haplic alisol (Areka Meteorological Station, 2008).

Eight Tef varieties namely Koye, Gimbichu, Quncho, Dega Tef, Keytena, Amarach and Ajora-1 varieties were collected from the Federal and regional Research center along with local checks, Ethiopia, and Regional Agricultural Research Institute. These materials were put into trial at Areka Agricultural Research center station farms at Areka and Hossana of Wolayta and Hadiya Zones during Meher season of 2008-2009. The trial was laid out in a randomized complete block design with three replications. Unit plot size was $9 \mathrm{~m}^{2}(3 \mathrm{~m} \times$ $3 \mathrm{~m}$ ) with spacing of $1 \mathrm{~m}$ between plots and $1.5 \mathrm{~m}$ between blocks. Planting was done by broadcasting at seed rate of $30 \mathrm{~kg} / \mathrm{ha}$. Sowing was done within the last week of July to $1^{\text {st }}$ week of August 2008 and 2009. All other recommended agronomic practices were kept normal and uniform to ensure normal plant growth and development. Seed yield of each plot was recorded and then converted into $\mathrm{kg} / \mathrm{ha}$. Data on plant height, panicle length, days to heading, days to maturity and grain yield were collected and subject to statistical analysis using SAS statistical software [10]. The farmers used matrix ranking to assess the most suitable varieties for their areas. The characters scored included; plant height, straw yield, thresh ability, days to maturity, seed colour, lodging, shattering, biomass yield and grain yield.

\section{Results and Discussion}

The analysis of variance revealed that there were highly significant $(\mathrm{p}<0.01)$ difference among varieties for days to maturity, plant height and panicle length, days to heading and grain yield at Areka (Table 1). These results are further supported by Fentie et al. [11] who reported considerable variation in the days to maturity, plant height and panicle length, days to heading and grain yield of different Tef varieties when planted over years. Koye gave the highest grain yield $(988.7 \mathrm{~kg} / \mathrm{ha})$ followed by Amarach (984.7 kg/ha) and Quncho (958.7 kg/ha) at Areka station (Table 1). Varieties koye, Amarach and Quncho had yield advantage of $15.9 \%, 15.4 \%$ and $12.4 \%$ over the local check respectively (Table 1).

At Hosanna station, the analysis of variance indicated that there were significant $(\mathrm{P}<0.01)$ difference among varieties for grain yield. This also agrees with the findings of Ashamo et al. [12] who evaluated 22 Tef genotypes at four locations and reported that significant variations in grain yield of Tef at all test locations. Similarly, in this study there were significant $(\mathrm{P}<0.01)$ difference among varieties for days to maturity, plant height and panicle length, days to heading. These results are in contrast with the earlier findings Fentie et al. [11] who noted that the effect of the different varieties used over years didn't show significant difference for plant height and panicle length. Variety Gimbichu gave the highest grain yield $(1656.1 \mathrm{~kg} / \mathrm{ha})$ followed by Quncho $(1571.3 \mathrm{~kg} /$ ha). Gimbichu and Quncho had yield advantage of $31.9 \%$ and $25.14 \%$ over the local check respectively. Gimbichu variety was found to be the earliest in maturity which was (99.5 days) at Hossana (Table 1). Grain yield was generally higher at Hossana than Areka $(1656.1 \mathrm{~kg} / \mathrm{ha})$ and (988.7) respectively (Tables 1 and 2).

The combined analysis of variance across locations over years among varieties revealed that there was significant difference for $50 \%$ days to heading and maturity, plant height, panicle length and grain yield. Varieties by year interaction indicated that there was highly significant $(\mathrm{p}<0.01)$ difference for panicle length and days to heading.

\begin{tabular}{|c|c|c|c|c|c|c|c|}
\hline Varieties & PH & PL & DH & DM & GY (kg/ha) & $\%$ YA/L & Rank \\
\hline Koye & $78.1 \mathrm{bc}$ & $29.8 \mathrm{~d}$ & $41.5 \mathrm{a}$ & $89.8 \mathrm{a}$ & $988.7 \mathrm{a}$ & 0.159 & 1 \\
\hline Gimbichu & $79.3 \mathrm{bc}$ & $27.6 \mathrm{~d}$ & $36.8 \mathrm{e}$ & $83.2 \mathrm{~d}$ & $927.7 \mathrm{ab}$ & - & 4 \\
\hline Quncho & $95.2 \mathrm{a}$ & $40.6 \mathrm{a}$ & $38.5 \mathrm{~cd}$ & $87.8 \mathrm{c}$ & $958.7 \mathrm{a}$ & 0.124 & 3 \\
\hline Degatef & $85.7 \mathrm{ab}$ & $37.8 \mathrm{ab}$ & $39.8 \mathrm{bc}$ & $89.5 \mathrm{ab}$ & $790.7 \mathrm{c}$ & - & 7 \\
\hline Keytena & $73 \mathrm{c}$ & $31.2 \mathrm{~cd}$ & $41.2 \mathrm{ab}$ & $87.5 \mathrm{c}$ & $781 \mathrm{c}$ & - & 8 \\
\hline Amarach & $92 \mathrm{a}$ & $33.3 \mathrm{~cd}$ & $38.2 \mathrm{de}$ & $87.8 \mathrm{c}$ & $984.3 \mathrm{a}$ & 0.154 & 2 \\
\hline Ajora-1 & $96.5 \mathrm{a}$ & $36.2 \mathrm{abc}$ & $39.5 \mathrm{~cd}$ & $89.8 \mathrm{a}$ & $795.7 \mathrm{c}$ & - & 6 \\
\hline Local & $79.5 \mathrm{bc}$ & $30.03 \mathrm{~cd}$ & $39.98 \mathrm{bc}$ & $88.5 \mathrm{bc}$ & $853.3 \mathrm{c}$ & - & 5 \\
\hline Mean & 84.9 & 33.32 & 39.4 & 88 & 983.3 & - & - \\
\hline CV $(\%)$ & 11.75 & 15.92 & 3.57 & 1.2 & 7.49 & - & - \\
\hline LSD (5\%) & 11.76 & 6.3 & 1.7 & 1.24 & 78.2 & - & - \\
\hline
\end{tabular}

Table 1: Mean grain yield and agronomic data of Tef varieties tested combined over years (2008 and 2009) at Areka.

\begin{tabular}{|c|c|c|c|c|c|c|c|}
\hline Varieties & PH & PL & DH & DM & GY (kg/ha) & $\%$ YA/L & Rank \\
\hline Koye & $74.5 \mathrm{~cd}$ & $30.2 \mathrm{~cd}$ & $46.5 \mathrm{ab}$ & $104.8 \mathrm{a}$ & $1445.7 \mathrm{~b}$ & 15.14 & 3 \\
\hline Gimbichu & $72.6 \mathrm{~d}$ & $26.9 \mathrm{~d}$ & $41.8 \mathrm{~d}$ & $99.5 \mathrm{c}$ & $1656.1 \mathrm{a}$ & 31.9 & 1 \\
\hline Quncho & $90.9 \mathrm{a}$ & $38.7 \mathrm{a}$ & $46.2 \mathrm{ab}$ & $104.3 \mathrm{a}$ & $1571.3 \mathrm{ab}$ & 25.14 & 2 \\
\hline Degatef & $78.9 \mathrm{bcd}$ & $35.3 \mathrm{ab}$ & $47.3 \mathrm{a}$ & $104.8 \mathrm{a}$ & $1258.7 \mathrm{c}$ & - & 5 \\
\hline Keytena & $71.1 \mathrm{~d}$ & $31 \mathrm{bcd}$ & $45.2 \mathrm{bc}$ & $102.5 \mathrm{~b}$ & $1240.6 \mathrm{c}$ & - & 7 \\
\hline Amarach & $85.3 \mathrm{abc}$ & $33.2 \mathrm{bc}$ & $43.2 \mathrm{~cd}$ & $102.8 \mathrm{~b}$ & $1259.3 \mathrm{c}$ & - & 4 \\
\hline Ajora-1 & $87.03 \mathrm{ab}$ & $34.9 \mathrm{ab}$ & $46.2 \mathrm{ab}$ & $105 \mathrm{a}$ & $1045 \mathrm{~d}$ & - & 8 \\
\hline Local & $81.4 \mathrm{abcd}$ & $33.8 \mathrm{bc}$ & $45.2 \mathrm{bc}$ & $104.7 \mathrm{a}$ & $1255.6 \mathrm{c}$ & - & 6 \\
\hline Mean & 80.24 & 32.99 & 45.2 & 103.4 & 1341.5 & - & - \\
\hline CV $(\%)$ & 11.75 & 11.98 & 3.96 & 1.1 & 9.83 & - & - \\
\hline LSD (5\%) & 11.12 & 4.7 & 2.11 & 1.33 & 155.6 & - & - \\
\hline
\end{tabular}

Key: $\mathrm{GY}=$ Grain yield $(\mathrm{kg} / \mathrm{ha}), \mathrm{PH}=$ plant height $(\mathrm{cm}), \mathrm{PL}=$ Panicle length $(\mathrm{cm})$ $H D=$ Days to Heading, $M D=$ Days to maturity and $Y A / L=-\%$ yield advantage over local variety

Table 2: Mean grain yield and agronomic data of Tef varieties tested combined over years (2008 and 2009) at Hossana. 
However, significant difference was not observed in plant height, days to maturity and grain yield. Varieties Gimbichu and Quncho gave the highest grain yield $(1343.4 \mathrm{~kg} / \mathrm{ha})$ and $(1318 \mathrm{~kg} / \mathrm{ha})$ respectively. Gimbichu gave the highest grain yield in both years and performed consistently over years at Hossana. In the combined analysis across locations over years, all farmers were consistently selected varieties koye and Quncho higher yielding and very white seed color whereas variety Amarach and Gimbichu gave higher yields than local checks are recommended for Areka and Hossnana areas specifically respectively. They also further argued that the high grain yielding potential of Quncho may be due its tallest plant height and bigger stem resisting relatively lodging compared to other improved varieties. Gimbichu and Quncho gave yield advantage of $21.9 \%$ and $19.6 \%$ over the local check respectively. Gimbichu, keytena and Amarach varieties took (91.3), (95) and (95.3) days to mature respectively (Table 3).

Farmers group around the stations visited and evaluated the research demonstration field twice at stage of maturity and harvesting for varietal choice. Accordingly, farmers set selection criteria of grain yield, maturity period and seed color. Based on their selection criteria, farmers selected Gimbichu for grain yield and for its short maturity period and ease of thresh ability and Quncho for its high yield, very white seed color and tolerance to long rainfall. Therefore, based on quantitatively measured agronomic traits (grain yield, seed color, and lodging, threshability and maturity date) and farmers' visual observation at field, koye and Quncho are recommended for production in Areka and Hossana areas of south Ethiopia and similar agro ecologies. Whereas varieties Amarach and Gimbichu showed specific adaptation for Areka and Hossana areas; respectively are recommended with their full production packages.

\section{Conclusions and Recommendation}

The combined analysis of variance revealed that varieties are significant for days to heading, maturity, panicle length, plant height and grain yield. Varieties Gimbichu, koye, Quncho and Amarach had a grain yield advantage of $21.9 \%, 15.4 \%, 19.6 \%$ and $6.8 \%$ over the local check respectively (Tables 3 and 4). Gimbichu was found to be the earliest maturing variety with higher grain yield. Farmers' main selection criteria were grain yield, biomass yield, straw yield, panicle length, lodging tolerance, thresh ability, maturity date and seed color. Based on their selection criteria, farmers selected Quncho for grain yield; biomass yield; straw yield, shattering resistance, tolerance to long rainfall and very white seed color, koye for grain yield and ease of thresh ability and white seed color. Gimbichu for its short maturity period and

\begin{tabular}{|c|c|c|c|c|c|c|c|}
\hline Varieties & PH & PL & DH & DM & GY $(\mathbf{k g} / \mathbf{h a})$ & $\%$ YA/L & Rank \\
\hline Koye & $76.3 \mathrm{~cd}$ & $30 \mathrm{~d}$ & $44 \mathrm{a}$ & $97.3 \mathrm{a}$ & $1272.1 \mathrm{a}$ & 0.154 & $3^{\text {rd }}$ \\
\hline Gimbichu & $75.95 \mathrm{~cd}$ & $27.3 \mathrm{e}$ & $39.3 \mathrm{e}$ & $91.3 \mathrm{~d}$ & $1343.4 \mathrm{a}$ & 0.219 & $1^{\text {st }}$ \\
\hline Quncho & $93.1 \mathrm{a}$ & $39.6 \mathrm{a}$ & $42.3 \mathrm{c}$ & $95.6 \mathrm{c}$ & $1318.2 \mathrm{a}$ & 0.196 & $2^{\text {nd }}$ \\
\hline Degatef & $82.4 \mathrm{~b}$ & $36.5 \mathrm{~b}$ & $43.6 \mathrm{ab}$ & $97.2 \mathrm{ab}$ & $1068.6 \mathrm{c}$ & - & $6^{\text {th }}$ \\
\hline Keytena & $72.05 \mathrm{~d}$ & $31.1 \mathrm{~d}$ & $43.2 \mathrm{abc}$ & $95 \mathrm{c}$ & $1054.2 \mathrm{c}$ & - & $7^{\text {th }}$ \\
\hline Amarach & $88.7 \mathrm{a}$ & $32.3 \mathrm{c}$ & $40.7 \mathrm{~d}$ & $95.3 \mathrm{c}$ & $1176.5 \mathrm{~b}$ & 0.068 & $4^{\text {th }}$ \\
\hline Ajora-1 & $91.8 \mathrm{a}$ & $35.6 \mathrm{~b}$ & $42.8 \mathrm{bc}$ & $97.4 \mathrm{a}$ & $964.5 \mathrm{~d}$ & - & $8^{\text {th }}$ \\
\hline Local & $80.4 \mathrm{bc}$ & $31.9 \mathrm{~cd}$ & $42.5 \mathrm{c}$ & $96.6 \mathrm{~b}$ & $1101.9 \mathrm{bc}$ & - & $5^{\text {th }}$ \\
\hline Mean & 82.6 & 33.2 & 42.3 & 95.7 & 1162.4 & - & - \\
\hline CV (\%) & 8.8 & 7.9 & 2.4 & 0.93 & 9.24 & - & - \\
\hline LSD (5\%) & 6.03 & 2.2 & 0.84 & 0.74 & 89.29 & - & - \\
\hline
\end{tabular}

Key: $\mathrm{GY}=$ Grain yield $(\mathrm{kg} / \mathrm{ha}), \mathrm{PH}=$ plant height $(\mathrm{cm}), \mathrm{PL}=$ Panicle length $(\mathrm{cm})$, $\mathrm{HD}=$ Days to Heading, $\mathrm{MD}=$ Days to maturity and $\mathrm{YA} / \mathrm{L}=-\%$ yield advantage over local variety

Table 3: Mean grain yield and agronomic data of Tef varieties tested across Areka and Hosanna combined over years (2008 and 2009).

\begin{tabular}{|l|c|c|c|c|c|c|c|c|c|c|c|}
\hline $\begin{array}{l}\text { Tef varieties in 2008 } \\
\text { and 2009 }\end{array}$ & \multicolumn{9}{|c|}{ Selection Criteria's } \\
\hline Areka & GY & MD & BY & SY & SC & TS & LG & SH & PH & Total & $\begin{array}{c}\text { Over all } \\
\text { Rank }\end{array}$ \\
\hline Koye & 3 & 2 & 2 & 2 & 2 & 3 & 1 & 2 & 2 & 19 & $3^{\text {rd }}$ \\
\hline Gimbichu & 3 & 3 & 2 & 2 & 2 & 3 & 1 & 2 & 2 & 20 & $4^{\text {th }}$ \\
\hline Quncho & 3 & 2 & 3 & 2 & 3 & 2 & 2 & 2 & 2 & 21 & $2^{\text {nd }}$ \\
\hline Degatef & 1 & 2 & 2 & 2 & 2 & 2 & 2 & 2 & 2 & 17 & $6^{\text {th }}$ \\
\hline Keytena & 1 & 2 & 1 & 2 & 1 & 3 & 2 & 2 & 1 & 15 & $8^{\text {th }}$ \\
\hline Amarach & 3 & 2 & 2 & 3 & 2 & 3 & 3 & 3 & 3 & 24 & $1^{\text {st }}$ \\
\hline Ajora-1 & 1 & 2 & 1 & 2 & 2 & 3 & 2 & 2 & 3 & 18 & $5^{\text {th }}$ \\
\hline Local & 1 & 2 & 1 & 2 & 2 & 3 & 2 & 1 & 2 & 16 & $7^{\text {th }}$ \\
\hline Hossana & & & & & & & & \\
\hline Koye & 3 & 2 & 2 & 3 & 2 & 3 & 1 & 2 & 2 & 20 & $3^{\text {rd }}$ \\
\hline Gimbichu & 3 & 3 & 2 & 3 & 2 & 3 & 1 & 2 & 3 & 22 & $2^{\text {nd }}$ \\
\hline Quncho & 3 & 2 & 3 & 3 & 3 & 2 & 3 & 2 & 1 & 23 & $1^{\text {st }}$ \\
\hline Degatef & 2 & 2 & 1 & 2 & 2 & 2 & 3 & 2 & 2 & 18 & $5^{\text {th }}$ \\
\hline Keytena & 1 & 2 & 2 & 2 & 1 & 3 & 2 & 2 & 2 & 17 & $6^{\text {th }}$ \\
\hline Amarach & 3 & 2 & 2 & 2 & 2 & 3 & 2 & 2 & 1 & 19 & $4^{\text {th }}$ \\
\hline Ajora-1 & 2 & 2 & 1 & 2 & 2 & 2 & 2 & 2 & 1 & 16 & $7^{\text {th }}$ \\
\hline Local & 1 & 2 & 2 & 2 & 1 & 3 & 2 & 1 & 1 & 15 & $8^{\text {th }}$ \\
\hline
\end{tabular}

Key: $\mathrm{GY}=$ Grain yield, $\mathrm{BY}=$ Biomass yield, $\mathrm{SY}=\mathrm{Straw}$ yield, $\mathrm{SC}=$ seed color $\mathrm{TS}=$ Thresh ability, $\mathrm{MD}=$ Days to maturity, $\mathrm{SH}=$ Shattering tolerance and $\mathrm{LG}=$ Lodging tolerance, Preference scale 0-3, 0=Poor, 1=fair, 2=Good, 3=Very good

Table 4: Matrix ranking of tef varieties at Areka and Hossana stations over years (2008 and 2009).

its higher grain yield for Hosanna areas and Amarach for its high yield, simplicity of threshability and very white seed color particularly to Areka areas. Therefore, based on researchers and farmers' preference, it was concluded that varieties Koye and Quncho are recommended for wider cultivation whereas varieties Gimbichu and Amarach are specifically recommended for Hosanna, Areka areas respectively.

\section{References}

1. Vavilove $\mathrm{NI}$ (1951) The origin, variation, immunity and breeding of cultivated plants (translated from Russian by K. Starr Chester). The Ronald's Press Co., New York, pp: 37-38

2. Hailu T, Seyfu K (2000) Production and importance of tef in Ethiopia Agriculture In: Tefera H, Belay G, Sorrels M (eds.), Narrowing the Rift: Tef research and development- Proceedings of the international Tef Genetics and improvement, 16-19 October 2000, Addis Ababa, Ethiopia.

3. CSA (2003) Urban bi-annual employment unemployment survey. 1st Year, Round 1.

4. Wondimu A, Mekbib F (2001) Utilization of tef in the Ethiopian diet. In: Tefera H Belay G, Sorrells M (eds.), Narrowing the rift: Tef research and development. Proceedings of the International Workshop on Tef Genetics and Improvement Debrezeit, Ethiopia, pp: 239-244.

5. Kornegay J, Beltran JA, Ashby J (1996) Farmer selections within segregating populations of common bean in Colombia: Crop improvement in difficulty environments. In: Eyzaguirre P, Iwanaga M (eds.), Participatory Plant Breeding, Proceeding of a workshop on participatory plant breeding, 26-29 July 1995 Wageningen, The Netherlands, IPGRI, Rome, Italy, pp: 151-159.

6. Fufa F, Grando S, Kafawin O, Shakhatreh Y, Ceccarelli S (2010) Efficiency of farmers' selection in a participatory barley breeding programme in Jordan. Plant Breeding 129: 156-161.

7. Courtois B, Bartholome B, Chaudhary D, McLaren G, Misra CH, et al. (2001) Comparing farmers and breeders rankings in varietal selection for low-input environments: a case study of rainfed rice in eastern India. Euphytica 122 537-550.

8. Getachew B, Hailu T, Anteneh G, Kebebew A, Gizaw M (2008) Highly clientoriented breeding with farmer participation in the Ethiopian cereal tef [Eragrostis tef (Zucc.) Trotter]. African J Agric Res 3: 022-028.

9. Danial D, Parlevliet J, Almekinders C, Thiele G (2007) Farmers participation 
Citation: Chondie YG, Bekele A (2017) Adaptability Evaluation and Selection of Improved Tef Varieties in Growing Areas of Southern Ethiopia. Hydrol Current Res 8: 266. doi: 10.4172/2157-7587.1000266

Page 4 of 4

and breeding for durable disease resistance in the Andean region. Euphytica 153: 385-396.

10. SAS Institute (2002) SAS System for Windows Release 9.2 Inc., Cary, NC, USA.

11. Fentie M, Demelash N, Jemberu $T$ (2012) Participatory on farm performance evaluation of improved Tef (Eragrostis tef $L$ ) varieties in East Belessa, north western Ethiopia. International Research Journal of Plant Science 3: 137-140.

12. Ashamo M, Belay G (2012) Genotype x Environment Interaction Analysis of Tef Grown in Southern Ethiopia Using Additive Main Effects and Multiplicative Interaction Model. Journal of Biology Agriculture and Healthcare 2: 66-72. 